\title{
BREASTFEEDING KNOWLEDGE AND PRACTICE OF HEALTH PROFESSIONALS IN PUBLIC HEALTH CARE SERVICES
}

\author{
Patrícia Kelly Silvestre \\ Maria Antonieta de Barros Leite Carvalhaes ${ }^{2}$ \\ Sônia Isoyama Venâncio ${ }^{3}$ \\ Vera Lúcia Pamplona Tonete 4 \\ Cristina Maria Garcia de Lima Parada ${ }^{5}$
}

Silvestre PK, Carvalhaes MABL, Venâncio SI, Tonete VLP, Parada CMGL. Breastfeeding knowledge and practice of health professionals in public health care services. Rev Latino-am Enfermagem 2009 novembro-dezembro; 17(6): 953-60.

This study evaluated breastfeeding knowledge and practice of professionals who care for infants at health care services in a city in the interior of São Paulo, Brazil. This epidemiological study was carried out with a population of 89 nurses and physicians. Their answers to a structured questionnaire were analyzed in total and by place of work through the test for difference between proportions (Chi-square) with the level of significance at $p<0.05$. Data analysis was performed according to the Ministry of Health recommendations. The significant differences found for knowledge and practice, according to place of work, were restricted to certain aspects. Results of average scores were slightly better for professionals from the basic care units. Regular and poor performance were found in different studied aspects regardless of place of work, which suggest that potential educational interventions in this subject should include professionals at all levels of health care.

DESCRIPTORS: breast feeding; education, nursing; inservice training

\section{CONOCIMIENTOS Y PRÁCTICAS DE PROFESIONALES DE LA SALUD SOBRE AMAMANTAMIENTO MATERNO EN SERVICIOS PÚBLICOS DE SALUD}

Se tuvo por objetivo evaluar los conocimientos y las prácticas sobre amamantamiento materno que tienen los profesionales que atienden lactantes en unidades de atención básica, o maternidades públicas, de un municipio del interior del estado de Sao Paulo, en Brasil. Es estudio epidemiológico, siendo la población compuesta por 89 enfermeros y médicos. Sus respuestas a un cuestionario estructurado fueron analizadas en su totalidad y según el local de trabajo, aplicándose la prueba de diferencia de proporciones (chi-cuadrado), considerándose $p<0,05$ como nivel crítico. Como parámetros de aciertos fueron consideradas las recomendaciones del Ministerio de la Salud. Las diferencias significativas para conocimientos y prácticas, según el local de trabajo, fueron restrictas a algunos aspectos, con resultados discretamente mejores de los puntajes promedios de aciertos de los profesionales de las unidades de atención básica. Independientemente del local de trabajo, se verificó desempeño regular y malo en diferentes aspectos estudiados, indicando que posibles intervenciones para la capacitación en esa temática deberán incluir profesionales de todos los niveles de atención a la salud.

DESCRIPTORES: lactancia materna; educación en enfermería; capacitación en servicio

\section{CONHECIMENTOS E PRÁTICAS DE PROFISSIONAIS DE SAÚDE SOBRE ALEITAMENTO MATERNO EM SERVIÇOS PÚBLICOS DE SAÚDE}

Objetivou-se avaliar conhecimentos e práticas sobre aleitamento materno de profissionais que atendem lactentes em unidades de atenção básica, ou maternidades públicas, de município do interior paulista, Brasil. É estudo epidemiológico, sendo a população composta por 89 enfermeiros e médicos. Suas respostas a um questionário estruturado foram analisadas no total e segundo o local de trabalho, aplicando-se o teste de diferença de proporções (qui-quadrado), considerando-se $p<0,05$ como nível crítico. Como parâmetros de acertos foram consideradas as recomendações do Ministério da Saúde. As diferenças significativas para conhecimentos e práticas, segundo o local de trabalho, foram restritas a alguns aspectos, com resultados discretamente melhores dos escores médios de acertos dos profissionais das unidades de atenção básica. Independente do local de trabalho, verificou-se desempenho regular e ruim em diferentes aspectos estudados, indicando que possíveis intervenções para a capacitação nessa temática deverão incluir profissionais de todos os níveis de atenção à saúde.

DESCRITORES: aleitamento materno; educação em enfermagem; capacitação em serviço

${ }^{1}$ RN, M.Sc. in Nursing, Faculdade de Medicina de Botucatu, Universidade Estadual Paulista "Júlio de Mesquita Filho", Brazil, e-mail: pakesil@yahoo.com.br. ${ }^{2}$ Nutritionist, Ph.D. in Nutrition, Assistant Faculty, Faculdade de Medicina de Botucatu, Universidade Estadual Paulista "Júlio de Mesquita Filho", Brazil, e-mail: carvalha@fmb.unesp.br. ${ }^{3}$ Physician, Ph.D. in Nutrition, Researcher, Instituto de Saúde da Secretaria de Estado da Saúde de São Paulo, Brazil, e-mail: soniav@isaude.sp.gov.br. ${ }^{4}$ RN, Ph.D. in Nursing, Assistant Faculty, Faculdade de Medicina de Botucatu, Universidade Estadual Paulista "Júlio de Mesquita Filho", Brazil, e-mail: vtonete@uol.com.br. ${ }^{5}$ RN, Ph.D. in Nursing, Adjunct Professor, Faculdade de Medicina de Botucatu, Universidade Estadual Paulista "Júlio de Mesquita Filho", Brazil, e-mail: cparada@fmb.unesp.br.

Disponible en castellano/Disponível em língua portuguesa SciELO Brasil www.scielo.br/rlae 


\section{INTRODUCTION}

Breastfeeding is essential ton infants' health and quality of life, presenting advantages to infants and the other subjects involved with this practice ${ }^{(1)}$.

Despite the current tendency to increase the period of breastfeeding, in Brazil this practice is far from what has been recommended: exclusive breastfeeding (EB) in children's first six months of life and complemented by other foods until two years of age or more ${ }^{(1)}$. For this reason, early weaning is a relevant concern for public health and has been the focus of technical and political interventions.

Scientific literature points to several factors that can negatively interfere with breastfeeding practice, among them: mother's lack of experience and belief that breast milk is weak; intercurrences with the puerperal breast; breastfeeding becoming a burden due to changes in women's daily life; mismatch between the mother's and infant's needs; external interferences of family members and the mothers' professional occupation $^{(2)}$.

On the other hand, receiving effective, professional or lay support during breastfeeding is associated with its success. Several international and Brazilian studies have shown this positive influence ${ }^{(3-}$ 5). A study carried out in Botucatu, SP, Brazil between 1995 and 2004 pointed to this relationship. It showed that the best results in the average duration of EB (increase of $82 \%$ ) and breastfeeding (increase of $50.9 \%$ ) in the period were related to the creation of the Human Milk Bank, to the implementation of Family Health Units and the increased number of health professionals involved with breastfeeding in the city ${ }^{(6)}$.

We proposed this study considering the importance of breastfeeding, its still limited duration and the influence of health professionals in its prevalence. The study's general objective was to evaluate the knowledge and practice related to breastfeeding for professionals who care for infants in the public health service in Botucatu, in the interior of São Paulo, Brazil. We also sought to identify potential differences, according to professionals' places of work: hospital facility or primary care service, aiming at developing educational interventions.

\section{METHOD}

This descriptive study in the field of health education was carried out in Botucatu, a medium size city located in the Mid-south region of the state of São Paulo, Brazil with approximately 120,000 inhabitants.

Botucatu has 16 primary care units, eight are traditional Basic Care Units (BCU) and eight are Family Health Units (FHU), and two maternal-infant hospitals: a teaching hospital, which is a tertiary care facility (TCF) and a philanthropic hospital, which is a secondary care facility (SCF).

All nurses and physicians who cared for infants in these services were considered eligible for this study. The only exclusion criterion was professionals working in more than one unit (12 cases), which would impede the intended comparative evaluation: hospital service versus primary care service. Five professionals did not participate in the study because they were either on vacation or on leave at the time of data collection. Thus, a population of 89 participants was included: 31 from the TLH, nine from the SLH, 29 from the BCUs and 20 from the FHUs totaling 55 nurses and 34 physicians.

Data collection was carried out in the second semester of 2007 through the application of a structured questionnaire with open and closed questions, which was developed based on a previously validated instrument ${ }^{(7)}$, adapted to meet the needs of this research and submitted to three experts in the area: two nurses and one nutritionist. These experts developed the answer sheet according to the Ministry of Health recommendations ${ }^{(8)}$.

To ensure anonymity during data collection, questionnaires were sent to the head nurses in the basic care units with no identification. After each professional filled out his/her own questionnaire, they put it in a sealed white envelope and returned it to the respective nurses. The researcher handed on the questionnaires to the participant professionals in the hospital facilities and they also returned questionnaires in a sealed white envelop to the researcher herself.

Variables related to the characterization of participants were: gender (male/female); age (years); place of work (BHU, FHU, SLH, TLH); time working in their respective facilities; (years) profession (nurse/ physician); time since graduation (years).

To analyze knowledge about breastfeeding, the following were investigated: knowledge about the Ten Steps to Success in Breastfeeding (yes/no, mention three steps); ideal duration of breastfeeding and $E B$ in months (4/6/12/24 or more); agreement with statements related to: breast milk composition 
and production, proper latch on, breast traumas, duration and frequency of feeding, discontinuing breastfeeding, breast hygiene and infant formulas (yes/no/do not know).

Practices related to breastfeeding were studied in the group of professionals considering: the frequency in which professionals advise against the use of pacifiers and advise the maintenance of breastfeeding when mothers have a job (most of the times/once in a while/never or very rarely). In the hospital context the following were investigated: the frequency professionals, in the delivery room, place infants to nurse; whether professionals check the newborn's sucking capacity with glucose serum and indicate the use of formula for healthy babies. Finally, the following were investigated in professionals working in basic care units: the frequency with which they address the advantages of breastfeeding; whether they observe feedings and provide orientation of how to care for breast traumas (most of the times/once in a while/never or very rarely).

One of the authors entered data, the consistency of which was tested based on associated questions. First, data analysis considered the frequency of answers of all the professionals. Scoring above $80 \%$ was considered a good performance, average between 50 and $79.9 \%$ and poor below $50 \%$.

Afterwards, the analysis was stratified by place of work and the test for difference between proportions was applied (Chi-square) with level of significance at 0.05 . Then, scores were checked and each correct answer scored 2.5. In total, 40 questions were considered: three addressing the Ten Steps to Breastfeeding Success, 32 addressing variables about knowledge and five about variables about practice, totaling 100 points.

The research project was submitted to and approved by the local Research Ethics Committee (Of. 307/2006-CEP) according to recommendations for research involving human beings. The studied participants signed free and informed consent agreements in order to participate in the study.

\section{RESULTS}

A brief characterization of the studied subjects revealed that the majority were nurses $(61.8 \%)$, female $(82 \%)$, between 25 and 35 years of age $(44.9 \%)$, with up to 10 years since graduation $(55.1 \%)$ and up to five years working in their current service $(43.8 \%)$.

A little more than a third $(34.8 \%)$ of the studied population knew three or more steps for breastfeeding success and the most cited step was: provide no artificial nipples to breastfeeding infants (Step 9) and the least mentioned: show mothers how to breastfeed and how to maintain lactation even if they should be separated from their infants (Step 5).

In regard to other studied variables addressing knowledge, there were generally good results in relation to the composition of breast milk and reasons to discontinue breastfeeding. For the remaining variables, one or more questions presented results that can be considered good, with the exception of proper latch on, whose results were below $80 \%$ and therefore were classified as average or poor. The majority of the interviewees correctly indicated the duration of breastfeeding and EB: $92.1 \%$ and $83.1 \%$ respectively (Table 1 ).

Table 1 - Expected answers and frequency of correct answers concerning breastfeeding knowledge of health professionals who care for infants. Botucatu, 2007

\begin{tabular}{|c|c|c|c|}
\hline \multirow{2}{*}{ Variables of knowledge } & \multirow{2}{*}{$\begin{array}{l}\text { Expected } \\
\text { answer }\end{array}$} & \multicolumn{2}{|c|}{ Correct answers } \\
\hline & & $\mathrm{N}^{\circ}$ & $\%$ \\
\hline \multicolumn{4}{|l|}{ Duration/frequency of feedings } \\
\hline Exhausting breast before changing & Yes & 79 & 88.7 \\
\hline $\begin{array}{l}\text { Preterm infants should breastfeed } \\
\text { every two hours }\end{array}$ & No & 29 & 32.6 \\
\hline $\begin{array}{l}\text { Full term infants should breastfeed } \\
\text { every three hours }\end{array}$ & No & 46 & 51.7 \\
\hline Limiting feeding to $15-20$ minutes & No & 53 & 59.6 \\
\hline \multicolumn{4}{|l|}{ Low milk production } \\
\hline Offering other foods to infant & Yes & 81 & 91 \\
\hline Offering other liquids & Yes & 72 & 80.9 \\
\hline Not milking in excess & Yes & 47 & 52.8 \\
\hline Discontinue feeding during the night & Yes & 50 & 56.2 \\
\hline Short feedings & Yes & 48 & 53.9 \\
\hline Maternal food deficit & No & 55 & 61.8 \\
\hline \multicolumn{4}{|l|}{ Proper latch on } \\
\hline $\begin{array}{l}\text { Hand on the infant's chin favors } \\
\text { searching reflex }\end{array}$ & No & 17 & 19.1 \\
\hline The baby's chin touches the breast & Yes & 67 & 75.3 \\
\hline The baby's cheeks are dimpled & No & 43 & 48.3 \\
\hline $\begin{array}{l}\text { More nipple is left above the baby's } \\
\text { mouth }\end{array}$ & Yes & 29 & 32.6 \\
\hline
\end{tabular}

Continue... 
Table 1 - Continuation

\begin{tabular}{|c|c|c|c|}
\hline \multirow{2}{*}{ Variables of knowledge } & \multirow{2}{*}{$\begin{array}{l}\text { Expected } \\
\text { answer }\end{array}$} & \multicolumn{2}{|c|}{ Correct answers } \\
\hline & & $N^{\circ}$ & $\%$ \\
\hline \multicolumn{4}{|l|}{ Composition of breast milk } \\
\hline $\begin{array}{l}\text { Water is sufficient up to the } 6 \text { th } \\
\text { month }\end{array}$ & Yes & 87 & 92.3 \\
\hline $\begin{array}{l}\text { The milk is fattier at the end of the } \\
\text { feeding }\end{array}$ & Yes & 78 & 87.6 \\
\hline Foremilk and hind milk are the same & No & 83 & 95.5 \\
\hline \multicolumn{4}{|l|}{ Reasons to interrupt breastfeeding } \\
\hline Active herpes lesion on breast & Yes & 83 & 93.3 \\
\hline Mothers with HIV & Yes & 88 & 98.9 \\
\hline $\begin{array}{l}\text { Mother works and there is no } \\
\text { daycare near }\end{array}$ & No & 89 & 100 \\
\hline \multicolumn{4}{|l|}{ Breast hygiene } \\
\hline Daily bath/daily change of bra & Yes & 74 & 83.1 \\
\hline $\begin{array}{l}\text { Washing breasts with soap and } \\
\text { water before breastfeeding }\end{array}$ & No & 64 & 71.9 \\
\hline $\begin{array}{l}\text { Using absorbent pad to keep } \\
\text { breasts dry }\end{array}$ & No & 69 & 77.5 \\
\hline \multicolumn{4}{|l|}{$\begin{array}{l}\text { Reasons for immediate supply of } \\
\text { formula }\end{array}$} \\
\hline Slight slowdown in weight gain & No & 66 & 74.2 \\
\hline $\begin{array}{l}\text { Absence of letdown reflex on the } 3 \text { rd } \\
\text { day postpartum }\end{array}$ & No & 66 & 74.2 \\
\hline $\begin{array}{l}\text { Mother will return to work in the } 3 \text { rd } \\
\text { month postpartum }\end{array}$ & No & 73 & 82 \\
\hline Child shows signs of being hungry & No & 52 & 58.4 \\
\hline \multicolumn{4}{|l|}{ Care for breast trauma } \\
\hline Milking and offering milk in a bottle & No & 79 & 88.8 \\
\hline $\begin{array}{l}\text { Using ointments before and after } \\
\text { feedings }\end{array}$ & No & 85 & 95.5 \\
\hline Discontinuing breastfeeding & No & 84 & 94.4 \\
\hline \multicolumn{4}{|l|}{ Ideal duration of breastfeeding } \\
\hline EB & 6 months & 82 & 92.1 \\
\hline Breastfeeding & $\begin{array}{l}24 \text { months } \\
\text { or more }\end{array}$ & 74 & 83.1 \\
\hline
\end{tabular}

In regard to practices related to breastfeeding, good results were observed among the professionals in the question that advises against pacifiers $(85.4 \%)$ and among those who work in basic care units on the question about their orientation regarding the advantages of breastfeeding (98\%). Average results were found in another question asked to all professionals: advise the maintenance of EB when the mother has a job (77.5\%) and in all questions asked to professionals working in the hospital facilities (Table 2).

Table 2 - Expected answers and frequency of correct answers related to breastfeeding practices of professionals who care for infants according to the level of health care: hospital $(n=40)$ and primary care $(n=49)$. Botucatu, SP, Brazil 2007

\begin{tabular}{|c|c|c|c|}
\hline \multirow{2}{*}{$\begin{array}{c}\text { Level of care/variables of } \\
\text { practices }\end{array}$} & \multirow{2}{*}{$\begin{array}{l}\text { Expected } \\
\text { answer }\end{array}$} & \multicolumn{2}{|c|}{$\begin{array}{l}\text { Correct } \\
\text { answers }\end{array}$} \\
\hline & & $\mathbf{N}^{\circ}$ & $\%$ \\
\hline
\end{tabular}

Primary care and hospital

$\begin{array}{lllll}\text { Advise against the use of pacifiers } & \text { Most of the times } & 76 & 85.4 \\ \text { Advise EB when mother works } & \text { Most of the times } & 69 & 77.5\end{array}$

Hospital Care

Placing the infant to nurse in the delivery room

Counter-indicating formula when the infant is healthy

Testing suction capacity with glucose serum

Most of the times $20 \quad 50$

Most of the times $\quad 29 \quad 72.5$

Never or rarely $\quad 21 \quad 52.5$

Basic care

Orienting about the advantages of breastfeeding

Most of the times $\quad 48 \quad 98$

Observing feedings

Most of the times $\quad 29 \quad 59.2$

Orienting how to care for breast

traumas

Most of the times $\quad 35 \quad 71.4$

A statistically significant difference was found in the health professionals' knowledge regarding breastfeeding according to place of work on the issue of the frequency of feedings, only on the question that proposed that full term newborns should breastfeed every three hours. There was also significant difference when factors related to low milk production where considered and the most significant reason reported to immediately offer formulas was the absence of the letdown reflex on the $3^{\text {rd }}$ day postpartum. Professionals from the hospital facilities presented lower scores in all these situations (Table 3). 
Table 3 - Frequency of correct answers to questions related to breastfeeding knowledge of professionals who care for infants according to the level of health care: hospital $(n=40)$ and basic care $(n=49)$. Botucatu, SP, Brazil 2007

\begin{tabular}{|c|c|c|c|c|c|c|}
\hline \multirow{3}{*}{ Variables of knowledge } & \multicolumn{4}{|c|}{ Score by level of care } & \multirow{3}{*}{$x 2^{* / *}$} & \multirow{3}{*}{$\mathbf{p}$} \\
\hline & \multicolumn{2}{|c|}{ Hospital } & \multicolumn{2}{|c|}{ Basic care } & & \\
\hline & $\mathbf{N}^{\circ}$ & $\%$ & $\mathbf{N}^{\circ}$ & $\%$ & & \\
\hline \multicolumn{7}{|l|}{ Duration/frequency of feedings } \\
\hline Exhausting breast before changing & 35 & 87.5 & 44 & 89.8 & 0 & $0.9969^{* *}$ \\
\hline Preterm infants should breastfeed every two hours & 9 & 22.5 & 20 & 40.8 & 3.36 & 0.0666 \\
\hline Full term infants should breastfeed every three hours & 16 & 40 & 30 & 61.2 & 3.97 & $0.0462^{* * *}$ \\
\hline Limiting feedings to $15-20$ minutes & 23 & 57.5 & 30 & 61.2 & 0.13 & 0.7217 \\
\hline \multicolumn{7}{|l|}{ Low breast milk production } \\
\hline Offering other foods to baby & 35 & 87.5 & 46 & 93.9 & 0.45 & $0.5003^{\star *}$ \\
\hline Offering other liquids & 27 & 67.5 & 45 & 91.8 & 6.94 & $0.0084^{* * / * * *}$ \\
\hline Not milking in excess & 17 & 42.5 & 29 & 59.2 & 2.45 & 0.1171 \\
\hline Interrupting night feedings & 24 & 60 & 26 & 53.1 & 0.43 & 0.5116 \\
\hline Short feedings & 23 & 57.5 & 25 & 51 & 0.37 & 0.5418 \\
\hline Maternal food deficit & 23 & 57.5 & 32 & 65.3 & 0.57 & 0.4508 \\
\hline \multicolumn{7}{|l|}{ Proper latch on } \\
\hline Hand on the infant's chin favors searching reflex & 15 & 37.5 & 28 & 57.1 & 3.40 & 0.0650 \\
\hline The baby's chin touches the breast & 30 & 75 & 37 & 75.5 & 0 & 0.9557 \\
\hline The baby's cheeks are dimpled & 9 & 22.5 & 8 & 16.3 & 0.54 & 0.4611 \\
\hline More nipple is left above the baby's mouth & 13 & 32.5 & 16 & 32.6 & 0 & 0.9877 \\
\hline \multicolumn{7}{|l|}{ Composition of breast milk } \\
\hline Water is sufficient up to the 6 th month & 39 & 97.5 & 48 & 97.9 & 0.33 & $0.5663^{\star *}$ \\
\hline Milk is fatter at the end of the feeding & 32 & 80 & 46 & 93.9 & 2.74 & $0.0979^{* *}$ \\
\hline Foremilk and hind milk are the same & 37 & 92.5 & 49 & 100 & 1.85 & $0.1738^{* *}$ \\
\hline \multicolumn{7}{|l|}{ Reasons to discontinue breastfeeding } \\
\hline Active herpes lesion on breast & 37 & 92.5 & 46 & 93.9 & 0.03 & $0.8672^{\star *}$ \\
\hline Mothers with HIV & 39 & 97.5 & 49 & 100 & 0.03 & $0.9185^{\star *}$ \\
\hline Mother works and there is no daycare near & 40 & 100 & 49 & 100 & - & - \\
\hline \multicolumn{7}{|l|}{ Breast hygiene } \\
\hline Daily bath/daily change of bra & 31 & 77.5 & 43 & 87.7 & 1.65 & 0.1985 \\
\hline Washing breasts with soap and water before breastfeeding & 26 & 65 & 38 & 77.5 & 1.72 & 0.1900 \\
\hline Using absorbent pad to keep breasts dry & 33 & 82.5 & 36 & 73.5 & 1.03 & 0.3099 \\
\hline \multicolumn{7}{|l|}{ Reasons for immediate supply of formula } \\
\hline Slight slowdown in weight gain & 27 & 67.5 & 39 & 79.6 & 1.68 & 0.1948 \\
\hline Absence of letdown reflex on the 3rd day postpartum & 18 & 45 & 34 & 69.4 & 5.39 & $0.0202^{* * *}$ \\
\hline Mother will return to work in the 3rd month postpartum & 32 & 80 & 30 & 61.2 & 3.67 & 0.0552 \\
\hline Child shows signs of being hungry & 35 & 87.5 & 38 & 77.5 & 0.88 & $0.3480^{* *}$ \\
\hline \multicolumn{7}{|l|}{ Care for breast trauma } \\
\hline Milking and offering milk in a bottle & 40 & 100 & 45 & 91.8 & 1.78 & $0.1819^{* *}$ \\
\hline Using ointments before and after feedings & 34 & 85 & 45 & 91.8 & 0.46 & $0.4974^{\star \star}$ \\
\hline Discontinuing breastfeeding & 37 & 92.5 & 47 & 95.9 & 0.05 & $0.8150^{* *}$ \\
\hline \multicolumn{7}{|l|}{ Ideal duration of breastfeeding } \\
\hline EB & 35 & 87.5 & 46 & 93.9 & 0.10 & $0.7524^{\star *}$ \\
\hline Breastfeeding & 32 & 80 & 42 & 85.7 & 0.51 & 0.4737 \\
\hline
\end{tabular}

The analysis of practices in relation to breastfeeding by place of work shows that there was significant difference only in relation to advising against the use of pacifiers and fewer interventions in hospital care (Table 4). 
Table 4 - Frequency of correct answers related to breastfeeding practices of professionals who care for infants, according to the level of care: hospital $(n=40)$ and basic care $(n=49)$. Botucatu, SP, Brazil 2007

\begin{tabular}{|c|c|c|c|c|c|c|}
\hline \multirow{3}{*}{ Variables of practice } & \multicolumn{4}{|c|}{ Scores by level of care } & \multirow{3}{*}{$x 2^{*} / * *$} & \multirow{3}{*}{$\mathbf{p}$} \\
\hline & \multicolumn{2}{|c|}{ Hospital } & \multicolumn{2}{|c|}{ Primary care } & & \\
\hline & $\mathbf{N}$ & $\%$ & $\mathbf{N}$ & $\%$ & & \\
\hline Advising against the use of pacifiers & 30 & 75 & 46 & 93.9 & 4.87 & $0.0273^{* * / * * *}$ \\
\hline Advising breastfeeding when mother has a job & 29 & 72.5 & 40 & 81.6 & 1.05 & 0.3045 \\
\hline Placing the baby to nurse in the delivering room & 20 & 50 & - & - & - & - \\
\hline Counter-indicating formula if infant is healthy & 29 & 72.5 & - & - & - & - \\
\hline Do not test suction capacity with glucose serum & 21 & 52.5 & - & - & - & - \\
\hline Orienting about breastfeeding advantages & - & - & 48 & 97.9 & - & - \\
\hline Observing feedings & - & - & 29 & 59.2 & - & - \\
\hline Orienting how to care for breast traumas & - & - & 35 & 71.4 & - & - \\
\hline
\end{tabular}

The minimum and maximum scores varied little. Considering the average scores, the basic care units presented a slightly better result than hospital facilities but with no statistically significant difference. The average scores revealed a regular performance in both cases, (Table 5).

Table 5 - Average values, minimum and maximum scores of questions related to breastfeeding knowledge and practice of professionals who care for infants, according to level of care: hospital $(n=40)$ and basic care $(n=49)$. Botucatu, SP, Brazil 2007

\begin{tabular}{lcccc}
\hline \multirow{2}{*}{ Level of care } & \multicolumn{3}{c}{ Scores } & \multirow{2}{*}{ * $^{*}$} \\
& Minimum & Maximum & Average & \\
\hline Hospital & 50 & 97.5 & $70.1( \pm 10.6)$ & \\
Basic care & 47.5 & 97.5 & $74( \pm 11.4)$ & 0.0942 \\
\hline
\end{tabular}

${ }^{*}$ Student's t-test

\section{DISCUSSION}

The study included professionals working in public health services, both in hospitals and basic care units in Botucatu, SP, Brazil, and allowed us to obtain a broad perspective of their knowledge and practice in breastfeeding. Adherence of professionals was high since only $4.7 \%$ of losses occurred due to the absence of professionals who were on vacation or leave. However, biases due to questionnaire's self-application cannot be discarded. We highlight that the use of a detailed instrument that was previously validated was important because the obtained results can help in the planning of future educational actions in the city.
In regard to knowledge, we verified that almost half of the professionals were not able to report any of the Ten Step to Breastfeeding Success. Considering that this subject is familiar to workers from hospital facilities ${ }^{(1)}$, we can affirm that the percentage of deficient knowledge was high. In a previous study, carried out in the same city, approximately $70 \%$ of professionals from maternity care facilities reported knowledge of the Ten Steps ${ }^{(9)}$.

Step 9 was the most cited and refers to the improper use of pacifiers and artificial nipples as they may lead to less frequent feedings, diminished stimulation and withdrawal of breast milk, leading to lower milk production and consequent weaning ${ }^{(10)}$.

The physiology of lactation shows, among other aspects, the importance of periodic sucking for milk production. Therefore, in the event mother and child should be temporarily separated, actions should be implemented to maintain lactation, though Step 5, which addresses this concern, was seldom reported.

Without question, the importance of adequate knowledge about the composition of breast milk and indications for discontinuing breastfeeding in the context of proper breastfeeding clinical management were obtained in relation to these aspects. Addressing the composition of breast milk included a question about whether breastfeeding provides sufficient hydration until the sixth month of the life of babies in EB and the professionals' performance regarding this question was good. A study carried out in São Paulo, Brazil addressing the frequency and determinants of breastfeeding in children up to four months of age showed a high prevalence of predominant breastfeeding, indicating that offering non-nutritious liquids, including water, is a widely disseminated practice in the state ${ }^{(4)}$. 
Equally important is the knowledge concerning proper latch on, and in this case the situation is preoccupying because health professionals are supposed to facilitate mothers' learning, since selflearning or learning mediated by lay people can be either insufficient or improper to enable breastfeeding success. Another preoccupying aspect refers to the duration/frequency of feedings, since agreement with rigid schedules was evident.

Regarding questions related to low levels of milk production, the professionals' performance was good when questions addressed the supply of other liquids and foods. However, their performance was regular when questions addressed less important aspects such as those related to milking in excess, feeding babies during the night or short feedings and maternal nutrition. These aspects are relevant because according to the Ministry of Health, among the main causes of hypogalactia are the offering of other foods and drinks, short, hurried and non-frequent feedings and discontinuing feedings at night ${ }^{(8)}$.

A slight slowdown in weight gain is not a reason to immediately offer formula, since this can sometimes be observed in healthy breastfeeding babies $^{(11)}$, though the performance of professionals was only regular on this question.

In the analysis of knowledge about hygiene and breast trauma, the results were good and regular. The breastfeeding clinical management requires proper breast hygiene to avoid complications such as breast trauma and mastitis. In a study carried out in Botucatu, SP, Brazil, the report about difficulties with breastfeeding was associated with the discontinuing of EB in infants younger than four months ${ }^{(12)}$.

Despite the high frequency of correct answers to questions about the duration of breastfeeding and $E B$, the obtained results were considered unsatisfactory because of the relevance of this knowledge to the practice and especially because official and scientific recommendations have been established and widely and continually disseminated for several years ${ }^{(1)}$.

The analysis of practices related to breastfeeding revealed good performance of professionals in the question about advising against the use of pacifiers. Even though government initiatives control, discourage and even prohibit publicity and use of rubber nipples in maternities, its use is still very frequent among Brazilian children. This fact might be related to representations people hold in relation to pacifiers, among others, that it symbolizes the child and soothes the baby, facilitating the mothers' work $^{(13)}$.

Although all participants agreed that the mothers' professional occupation is not a reason to offering formula, professionals presented a regular performance regarding orientation about how to maintain breastfeeding in such situations.

The evaluation of practices of professionals working in the basic health service was good in relation to questions addressing the advantages of breastfeeding and regular in relation to questions addressing the need to observe feedings and care for breast trauma. Observing feedings and being attentive to the maternal posture and to the newborn's latch on can provide important support to health professionals about the risks of early weaning. In regard to trauma, even taking into account that the results of knowledge were good for the majority of questions, in practice, only $71.4 \%$ of the professionals addressed this subject in the majority of consultations.

There still are professionals who test babies' sucking capacity with glucose serum among those who work in hospital facilities despite evidence indicating that it compromises breastfeeding. There are also those who prescribe formula for newborns with no problems whatsoever and only half of professionals allow mothers to initiate early breastfeeding in the majority of deliveries. A study aiming to categorize the group of mothers/newborns with a special need to have support to experience a successful breastfeeding beginning and also verify care practices associated with breastfeeding, indicates that the use of formulas and glucose serum was associated with the worst scores when it evaluated the following: response to the newborn's stimuli, the body position of mother/child and proper sucking ${ }^{(14)}$.

The analysis by place of work of knowledge and practices scores regarding breastfeeding evidenced significant differences, especially concerning: knowledge related to the frequency of feedings of full term babies; supply of liquids to babies as a factor related to low milk production; absence of letdown reflex on the $3^{\text {rd }}$ day postpartum justifying the supply of formulas; and when questions addressed practices about providing orientation to mothers to avoid the use of pacifiers. The performance of basic care units was better than that observed in hospital facilities in all cases. 
Despite these findings, the small variation between results, when place of work was taken into account, lead to the conclusion that the professionals' performance was similar. This fact draws attention because, currently, the strategy of breastfeeding best established in Brazil is the Baby-Friendly Hospital Initiative, which focuses on hospital care.

Based on the previously discussed, educational interventions in the subject should be promoted for all professionals. From this perspective, on-going health education has an important role to play. Thus, the promotion of professional development actions in breastfeeding is suggested. These actions should be carried out in and out of institutions, which should be coresponsible for contextualized and integral actions with a view to promote the required quality of this essential health practice.

\section{REFERENCES}

1. World Health Organization (WHO). Global strategy on infant and young child feeding. Geneva: WHO; 2001.

2. Ramos CV, Almeida JAG. Alegações maternas para o desmame: estudo qualitativo. J Pediatr 2003 setembrooutubro; 79(5):385-90.

3. Britton C, McCormick FM, Renfrew MJ, Wade A, King SE. Support for breastfeeding mothers [Cochrane Review]. Cochrane Database Syst Rev 2007;(4).

4. Venâncio SI, Escuder MML, Kitoko P, Réa MF, Monteiro $\mathrm{CA}$. Freqüência e determinantes do aleitamento materno em municípios do Estado de São Paulo. Rev Saúde Pública 2002 junho; 36(3):313-8.

5. Coutinho SB, Lira PIC, Lima MC, Ashworth A. Comparison of the effect of two systems for the promotion of exclusive breastfeeding. Lancet 2005; 366(9491):1094-100.

6. Ferreira L, Parada CMGL, Carvalhaes MABL. Tendência do aleitamento materno em município da região centro-sul do estado de São Paulo: 1995-1999-2004. Rev Nutrição 2007 maio-junho; 20(3):265-73.

7. Becker D. No seio da família: amamentação e promoção da saúde no Programa de Saúde da Família. [dissertação]. Rio de Janeiro (RJ): Escola Nacional de Saúde Pública; 2001.

8. Ministério da Saúde (BR). Guia alimentar para crianças menores de dois anos. Brasília (DF): Ministério da Saúde; 2002.

9. Manzini FC, Parada CMGL, Juliani CMCM. Aleitamento materno na sala de parto: a visão dos profissionais de saúde. In: Anais do $8^{\circ}$ Simpósio Brasileiro de Comunicação em Enfermagem [Anais online]; 2002 Maio; São Paulo, SP, Brasil. 2002 [citado 24 jun 2008]. Disponível em: URL: http:// www.proceedings.scielo.br/scielo.php?script $=$ sci_arttext \&pid= MSC0000000052002000200024\&Ing=pt\&nrm=van. 10. Sertório SCM, Silva IA. As faces simbólica e utilitária da chupeta na visão de mães. Rev Saúde Pública 2005 abril; 39(2):156-62.

11. Marques RFSV, Lopes FA, Braga JAP. O crescimento de crianças alimentadas com leite materno exclusivo nos primeiros 6 meses de vida. J Pediatr 2004 outubro; $80(2): 99-105$.

12. Carvalhaes MABL, Parada CMGL, Costa MP. Fatores associados à situação do aleitamento materno exclusivo em crianças menores de 4 meses, em Botucatu-SP. Rev Latinoam Enfermagem 2007 janeiro-fevereiro; 15(1):62-9.

13. Réa MF. O pediatra e a amamentação exclusiva. J Pediatr 2003 novembro-dezembro; 79(6):479-80.

14. Carvalhaes $M A B L$, Corrêa $C R H$. Identificação de dificuldades no início do aleitamento materno mediante aplicação de protocolo. J Pediatr 2003 janeiro-fevereiro; 79(1):13-20. 